\title{
Anksiyete araştırmalarında kullanılan sıçan davranış modelleri
}

\author{
Models of rat behavior used for studies of anxiety
}

\author{
Aslı AYKAÇ, Kaya SÜER, Cahit TAŞKIRAN
}

\section{ÖZET}

Klinik öncesi çalışmalar kapsamında oluşturulan hayvan modelleri ile yeni ilaçların anksiyolitik etkileri araştırılmaktadır. $\mathrm{Bu}$ modellerde en sık kullanılan hayvanlar sıçanlar ve farelerdir. Anksiyete oluşturulan hayvanlarda; çevreyi araştırma ve tanıma davranışlarındaki değişiklikleri inceleyerek, ilaca verilen yanıta bu davranışlardaki değişimlerin saptanması araştırmaların temelini oluşturmaktadır. İnsanlarda görülen anksiyete davranışlarını tam olarak karşılamamakla birlikte hayvan modellerinde sıçanlardaki bu davranışlar modelin esasını oluşturmaktadır. Stres yaratan etken olarak; elektrik şoku, kafeslere eğim verilmesi, olfaktor bulbektomi, ortamın yükseltilmesi, aydınlatmanın değiştirilmesi, sosyal izolasyon, sualtı travmaları, saldırgan hayvanın kendisine ya da saldırgan hayvana ait ipuçlarına (saldırgana ait koku, tüy, idrar vb) maruz bırakma kullanılmaktadır. Oluşturulan strese karşı bu çalışmalarda genellikle aşırı irkilme, bilişsel bozukluklar, gelişmiş korku, düşük sosyal etkileşim gibi anksiyete davranışlarındaki değişimler ölçülmektedir. Sik kullanılan modeller arasında; açık alan, zorunlu yüzme, çatışma testleri, tekrarlayan stres uygulamaları, kuyruktan asma, yükseltilmiş labirentler, sosyal izolasyon, uzun süreli tek bir strese maruz birakma, kronik hafif stres ve saldırgan ya da saldırgan ile ilgili ipuçlarına maruz bırakma testlerini saymak mümkündür.

$\mathrm{Bu}$ derlemede, farklı stresörler ile anksiyete oluşturmada kullanılan sıçan modelleri tanımlanmaktadır. Modellerin özellikleri ve kullanım alanları gözden geçirildiğinde; kolay oluşturulabilir

Aslı Aykaç (ヌ)

Biyofizik Anabilim Dalı, Tıp Fakültesi, Yakın Doğu Üniversitesi, Lefkoşa, KKTC

e-mail:aykacasli@yahoo.com

Kaya Süer

Enfeksiyon Hastalıklart ve Klinik Mikrobiyoloji Anabilim Dall, Tip Fakültesi, Yakın Doğu Üniversitesi, Lefkoşa, KKTC

Cahit Tașkıran

Tip Ĕ̈itimi Anabilim Dal, Tıp Fakültesi, Yakın Doğu Üniversitesi, Lefkoşa, KKTC

Gönderilme/Submitted: 17.10.2014

Kabul/Accepted: 03.12 .2014 ve tekrarlanabilir oluşları, yeni geliştirilmekte olan ilaçların ya da mevcut benzer ilaçların anksiyeteyi önleme ve tedavi edici etkileri daha etkin olarak araştırılmaktadır.

Anahtar kelimeler: Anksiyete, Sıçan davranışları, Hayvan modelleri.

\begin{abstract}
This review focuses on the methods of study that investigated the anxiolytic effects of new drugs with animal models. In a research setting, researchers investigate inquiry and recognition behavior changes of animals with anxiety in response to drug therapy. This forms the basis of a research. Although, "anxious" behaviors of rats do not exactly match the actual human behavior, they are still used as a model of human behavior. Several different stressor agents have been used including electric shocks, tilting the cage, olfactory bulbectomy, elevation of the setup, changing the lighting situation, under water trauma or exposure to predator materials. In these studies, generally the reaction to the stress is tested by observing the changes in the "anxious" behavior, cognitive impairment, fear and decreased social interaction. Frequently used models are; open field test, forced swimming test, social isolation, conflict tests, repeated stress test, tail suspension test, elevated maze tests, single prolonged test and chronical mild stress predator scane test.

We explain various rat models and their properties and show how they are used to create anxiety with different stressor agents. Ease and repeatability of these models suggest that they are effective for studying drugs for the prevention and treatment of anxiety.
\end{abstract}

Keywords: Anxiety, Rat behavior, Animal models.

\section{Giriş}

Anksiyete, farklı durumların neden olduğu, kişinin içten ya da dıştan algıladığı tehlikeye karşı duyduğu endişe, 
hatta korku duygusudur. Farklı olaylar ya da oluşumlar anksiyeteye sebep olabilir. Anksiyete semptom olarak bir çok mental hastalıkta karşımıza çıkmaktadır [1].

Son yıllarda dünyada anksiyetinin sıklıkla görülmesi bu hastalığın tedavisi ile ilgili gerek klinik, gerekse preklinik çalışmaların artmasına yol açmıştır. Klinik öncesi çalışmalarda, yapılan hayvan modelleri ile yeni ilaçların anksiyolitik etkileri araştırılmaktadır. $\mathrm{Bu}$ modellerde kemirgenler arasında en sık kullanılanları sıçanlar ve farelerdir. Bu türler, zemindeki emosyonel ve motivasyonel işlevlerin altındaki mekanizmayı araştırmada yoğun olarak kullanılmaktadır.

Sıçanlar, yeni çevreye ilk girdiklerinde, alanın kuytu kısımlarında ya da duvar kenarları boyunca ilerleyip onlar için korunmasız olan alanı tanımak üzere çevrede bulunan nesneleri ve potansiyel tehlikeleri araştırmaya başlarlar. Araştırma davranışları olarak sıçanlar; iki ayağı üzerine kalkma (vertikal aktivite), tırmanma, havayı koklama, süslenme gibi davranışlar sergilerler. Tüm canlı türlerinde olduğu gibi sıçanlar da türlerini tehdit eden bir uyarı ile karşılaştıkları zaman kendi türlerine özgün davranışlar sergilemektedirler. Sıçanlar, kendini tehdit eden şeyin ne olduğunu anlamak, hakkında bilgi toplamak veya çevreyi incelemek için risk ölçümü davranışı olarak nitelendirilen havayı koklama ve uzanma hareketleri ile savunmaya geçmektedirler. Sıçanlar, kendileri için korunmasız alan olarak gördükleri alanlarda bu davranışlarını arttırmış olmaları anksiyete ile yakından ilişkilidir. Anksiyete durumu arttıkça sıçanların araştırma davranışları azalmaktadır [2].

Sıçanların bilmedikleri bir alanı araştırırken ortamın aydınlık ya da karanlık olması araştırma davranışlarını etkilemektedir. Sıçanlar, bilmedikleri çevrenin karanlık alanlarında hareket etmede rahat hissederlerken, parlak ışıklı alanlardan uzak durmayı tercih ederler. Sıçanın ortamın karanlık alanlarında hareket etmesi ve aydınlık alanda hareketten sakınması anksiyetenin göstergesidir. Sıçanın karanlık bölmede kalıp aydınlık bölmeye ilk geçiş süresindeki uzama anksiyetedeki artışa paralel olarak değerlendirilmektedir [3]. Sıçanların bilmedikleri bir çevreden uzak durmasında etkili olan bir diğer etken ise alanın yükseltilmiş olmasıdır. Sıçanın yükseltilmiş alanın kıyı noktasını görmesi de, o alandan sakınması için iyi bir etkendir. Korunma davranışı, hayvanın görme kapasitesi, lokomotor aktivitesi, motive edici etkenler ve onun araştırma yöntemine bağlı olarak değişebilmektedir [4]. Yeni bir çevreye giren siçanlar yemek yemede isteksizleşirler ve yemeği yemeleri için geçen süre uzamaktadır $[2,5,6]$.

Stres kaynaklı anksiyete ile ilgili literatürde yer alan hayvan modelleri çok çeşitlilik göstermektedir [7]. Deney hayvanlarının kullanıldığı anksiyete modelleri ile insandaki duruma benzer değişiklikler taklit edilmeye çalışılmaktadır. Ancak insandaki durumu bire bir yansitan bir hayvan modeli bulunmamaktadır [8]. Hayvan modelleri her ne kadar insanda görülen anksiyete davranışlarını tam olarak karşılamasa da aşağıda sınıflandırılmaya çalışılan sıçan davranışları araştırmalarda kullanılan modeller için çıkış noktası oluşturmaktadır.

\section{Anksiyete oluşturmada kullanılan sıçan modelleri}

Sıçanların kullanıldığı klinik öncesi araştırmalarda anksiyete oluşturmada çeşitli tiplerde stresörler kullanmıştır $[9,10]$. Stresör olarak elektrik şoku, kafeslere eğim verilmesi, koku alma duyusunun yok edilmesi, ortamın yükseltilmesi, 1şıklandırma seviyeleri değiştirilmiş ortamlar, sosyal izolasyon, sualtı travmaları (su dolu ortamlar), saldırgan hayvanın kendisine ya da saldırgan hayvana ait ipuçlarına (saldırgana ait koku, tüy, idrar vb.) maruz bırakma kullanılmaktadır. Sıçanda anksiyete oluşup oluşmadığının izlenmesi ya da oluşan anksiyetenin skorlanmasında çeşitli testler kullanılmaktadır. $\mathrm{Bu}$ testler arasında; açık alan, zorunlu yüzme, çatışma testleri, tekrarlayan stres uygulamalar1, kuyruktan asma, yükseltilmiş labirentler, uzun süreli tek bir strese maruz birakma, kronik hafif stres ve saldırgan ya da saldırgan ile ilgili ipuçlarına maruz bırakma testlerini saymak mümkündür [10-15].

\section{Açık alan testleri}

Açık alan korkusu ile tetiklenen anksiyete, spontan lokomotor aktivitelerin ve sedasyonun tespitinde kullanılan testtir. Açık alan testi, yuvarlak, kare veya dikdörtgen bir alanda sıçanın kaçışını engelleyen duvarlara yakın bir yere ya da merkeze bırakılıp günün değişik saatlerinde hareketlerinin gözlendiği bir testtir (Şekil 1). Bu modelde kullanılan test alanlarının yanısıra, aydınlatma seviyeleri, kullanılan aydınlatma çeşitleri hatta alanın aydınlatılan yerleri de farklı olabilir. Ayrıca alanda platform, kolon, tünel gibi bölümler de yer alabilir $[16,17]$.

Açık alan testinde zaman ölçütleri olarak; merkeze ilk giriş latensi, merkezde geçirilen süre ve duvar diplerinde geçirilen süreler değerlendirilmektedir. Aydınlık- 
karanlık tercih testinin zaman değerlendirilmesinde çeşitli parametreler değerlendirilmektedir. Bunlar; sıçanın aydınlık bölümden karanlık bölüme (ya da tam tersi olan karanlık bölümden aydınlık bölüme) ilk geçişinde geçen süre, sıçanın tüm test süresi boyunca aydınlık alanda geçirdiği toplam süre ve siçanın test süresi boyunca karanlık alanda geçirdiği toplam süredir. Sıçanların kendilerini savunma için sergiledikleri donakalma hareketi ise en az 10 solunum sayısı kadar geçen sürede hiçbir hareket yapmaması olarak değerlendirilmektedir [16, 17].

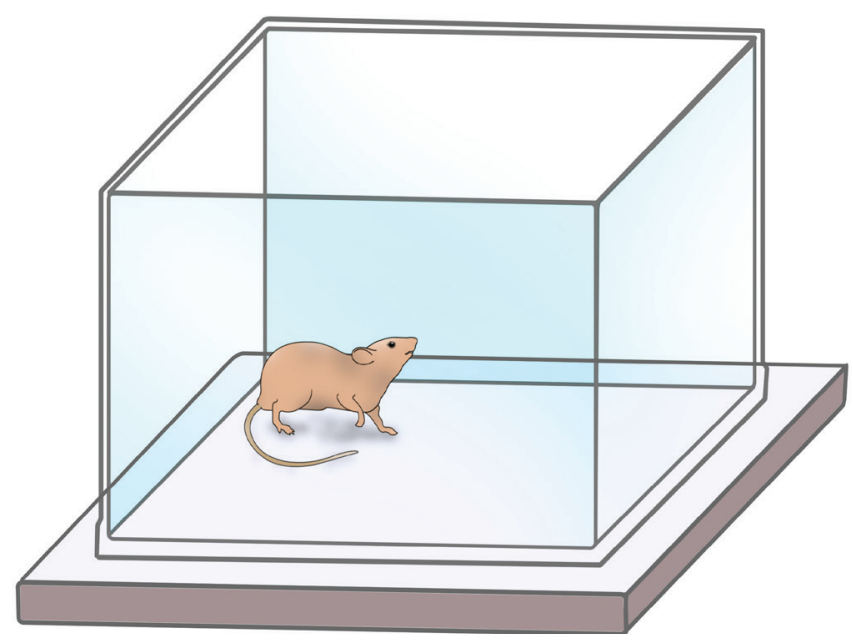

Şekil 1. Açık alan testi düzeneği

Lokomotor aktivitesi olarak; deney düzeneğinin merkezinde ve duvar diplerinde sıçanın geçtiği karelerin sayısı, merkezden geçiş sıklığı kaydedilmektedir. Açık alan testinde davranış ölçütleri olarak incelenen parametreler; duvara dayalı olarak ayağa kalkma davranışı (düzenekten dışarı çıkma isteği), serbest ayağa kalkma davranışı (düzeneği araştırma isteği) ve merkezde serbest ayağa kalkma davranışıdır.

Aydınlık-karanlık tercih testinde davranış ölçütleri olarak; aydınlıktan karanlığa baş uzatma sayısı, karanlıktan aydınlığa baş uzatma sayısı, karanlık bölüme geçiş sıklığı, aydınlık alandan karanlık alana ve karanlık alandan aydınlık alana toplam giriş-çıkış sayısı skorlanmaktadır. Bu verilerin değerlendirilmesi sırasında; merkezi alanda geçirilen toplam sürenin azalması, merkezi alana geçiş sayısının azalması ve vertikal aktivitedeki artış, sıçandaki anksiyolitik etkinin varlığı ile doğru orantılıdır. Bu düzenekte duvarlara yakın alanlar sıçan için korumalı, güvenli alanlarken, merkezi alan sıçan için anksiyojenik etki yaratmaktadır $[16,17]$.

\section{Zorunlu yüzme testleri}

Morris'in su tank1 olarak da bilinen Porsolt'un zorunlu yüzme testi, sıklıkla depresyon ve anksiyete araştırmalarında, antidepresanların etkinliğini araştırmada kullanılmaktadır. $\mathrm{Su}$ dolu tankın içinde sıçanların kaçabilmeleri için bir platformun bulunduğu test düzeneği; $45 \mathrm{~cm}$ yüksekliğinde pleksiglastan yapılmış silindir kabın $30 \mathrm{~cm}$ 'sinin $25^{\circ} \mathrm{C}$ opak su ile doldurulmasıyla oluşturulmaktadır. Deneylerin ilk aşamalarında sıçanların kaçmak için kullanabilecekleri platform, deney düzeneğinde yer alırken, anksiyetenin değerlendirileceği deneyler sırasında platform deney düzeneğinden çıkarılmaktadır. Onar dakikalık periyotlarda gerçekleştirilen deneylerde sıçanların ortamdan kurtulmak için çabalamaktan vazgeçip tamamen hareketsizleştiği süre skorlanmaktadır. Bu davranışsal parametreler dışında sıçanların tankın içindeki davranışları; yüzme ve tırmanma hareketleri de kaydedilmektedir [18-20]. Deneylerde siçanın ortamdan kurtulmak için platformu bulma çabasından kısa süre içinde vazgeçmesi anksiyetedeki artış ile doğru orantılı olarak artmaktadır.

\section{3. Ödül-ceza sistemine dayalı çatışma testleri}

Çatışma testleri genellikle potansiyel anksiyolitik ajanların etkilerini araştırmada kullanılmaktadır. Çatışma testleri önce cezasız sonra cezalı ödüllendirme bölümlerinden oluşmaktadır. Ödül olarak yiyecek ve/veya su kullanılmaktadır (Şekil 2).

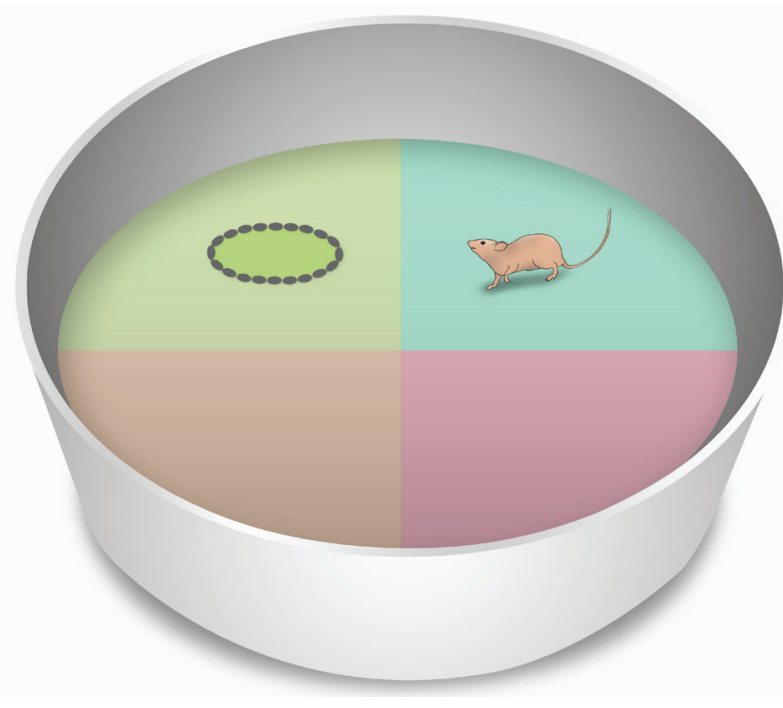

Şekil 2. Ödül testi düzeneği

Şartlı zıtlaşma testinde; su ve yem vererek ödüllendirme ve ayaktan şok vererek cezalandırma sistemi kullanılmaktadır. 
Vogel zıtlaşma testinde; elektriksel uyarılar sıçana su içerken verilmektedir. Bir gün boyunca sussuz bırakılan sıçana $5 \mathrm{dk}$ su içme izninin verilmesi sırasında 21. yalamadan itibaren ayaktan şok uygulanmaktadır. Geller Seifter çatışma testi ise aç ve susuz bırakılan sıçana kafesin tabanında yer alan pedala her basışında şekerli su ile ödüllendirme sistemi uygulanır. Sonraki bölümlerde ödül sistemi ile birlikte pedala bastıkça bellirli aralıklar ile ayaktan şok uygulanmaktadır [2, 21, 22].

$\mathrm{Bu}$ testlerin ödül etaplarında, sıçanın pedala kaç kez basmış olduğu veri olarak toplanmaktadır. Testin cezalı ödüllendirilme bölümünde yine sıçanın pedala basış sayısı veri olarak toplanmaktadır.

\section{Yükseltilmiş labirent testleri}

Yerden yüksekliği $50 \mathrm{~cm}$ olan sıfir ve artı şekillerinde, uzunlukları $50 \mathrm{~cm}$ ve genişlikleri $10 \mathrm{~cm}$ ' lik açık ve kapalı alanlar içeren labirentler kullanılmaktadır (Şekil 3a, 3b). Sıçanların bilmedikleri çevreyi tanıma davranışları sırasında alanın yükseltilmiş olması anksiyeteyi arttırıcı bir etkendir [23]. Yükseltilmiş labirent deneylerinde sıçanlar genellikle yüzü açık olan kollardan birine bakar şekilde alanın merkezine doğru bırakılırlar. Sıçanın açık kolu görecek şekilde labirent üzerine yerleştirilmesinin nedeni, sıçanların doğuştan açık ve yüksek yerlerden korkuyor olmalarıdır [4, 24]. Anksiyeteye işaret eden davranış değerlendirmeleri; kapalı kol üzerinde geçen zamanın uzaması, donakalma süresindeki artış, açık kola giriş sayısındaki azalma, merkezi alanda gezinme süresindeki azalma ve iki ayağı üzerinde kalkıp havayı koklama sayısındaki ve süresindeki artışlardır [25].

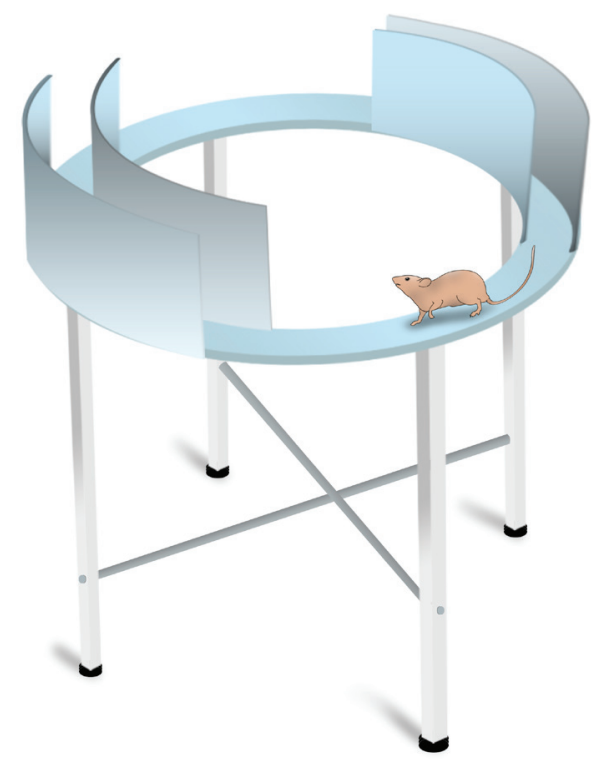

Şekil 3a. Yükseltilmiş sıfır labirent düzeneği

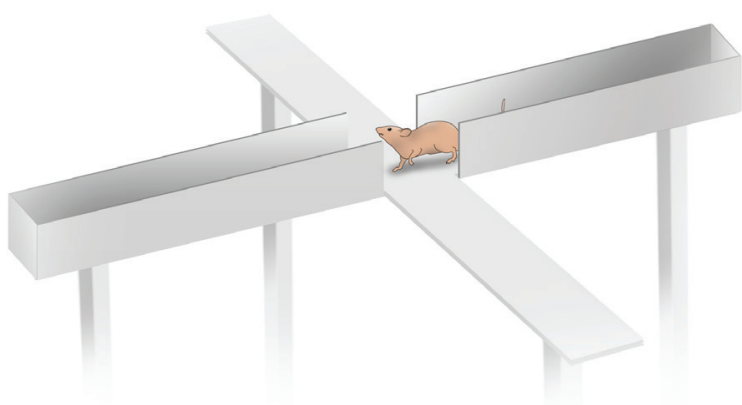

Şekil 3b. Yükseltilmiş artı labirent düzeneği

\section{Kronik hafif stres testleri}

Siçanların tekrarlayan şekilde çeşitli ve hafif stresörlere maruz bırakılması üzerine kurulu bu modellerde; kafeslerine eğim verilmesi, kafeslerin sarsılması, kafeslerin altlık malzemelerinin 1slatılması, sosyal ortamlarından izole edilmeleri, gece/gündüz sikluslarının ters döndürülmesi gibi stresörler dönüşümlü olarak uygulanmaktadır. Aç bırakıldıktan sonra dönüşümlü uygulanan stresörler ile karşılaşan sıçanların kafeslerine geri alındıktan sonra anksiyetedeki artışa paralel olarak yeme-içme ve hareketlerinde azalma meydana geldiği belirlenmiştir [26].

\section{Sosyal etkileşim testleri}

Sosyal etkileşim testinde sıçanlar ya gruplarından izole edilmektedirler ya da çok daha kalabalık ve büyük (agorafobi) kafeslere alınmaktadırlar (Şekil 4). Gruplar halinde izole edilen sıçanlarda hiyerarşik bir yapı oluşmaktadır. Gruplar arasında baskın karakteri sergileyemeyen sıçanlarda anksiyete benzeri davranışlar görülmeye başlamaktadır. Anksiyetenin etkisi ile sıçanın hareket ve oyun davranışlarında, yeme-içmede ve sosyal etkileşimde azalma görülmektedir [27].

Sıçanın sosyal grubundan ayrılmış olması, kendi yaşam koşullarına göre içinde bulunduğu alanın çok büyük olması gibi etmenler de anksiyetedeki artış1 tetiklemektedir. Yapılan çalışmalarda, sosyal izolasyonlu sıçanların açık alan test düzeneği merkezine daha kısa sürede girdiği, düzeneğin merkezinde geçirilen sürenin uzadığı görülmüştür. Bu tip değişiklikler anksiyete benzeri davranışlarda azalma olarak değerlendirilmektedir. Çalışmaların bir kısmında anksiyete davranışlarında azalma bulunmasına rağmen bir kısım çalışmalarda ise anksiyetede artı̧̧ gösterilmiş̧tir [28, 29]. 


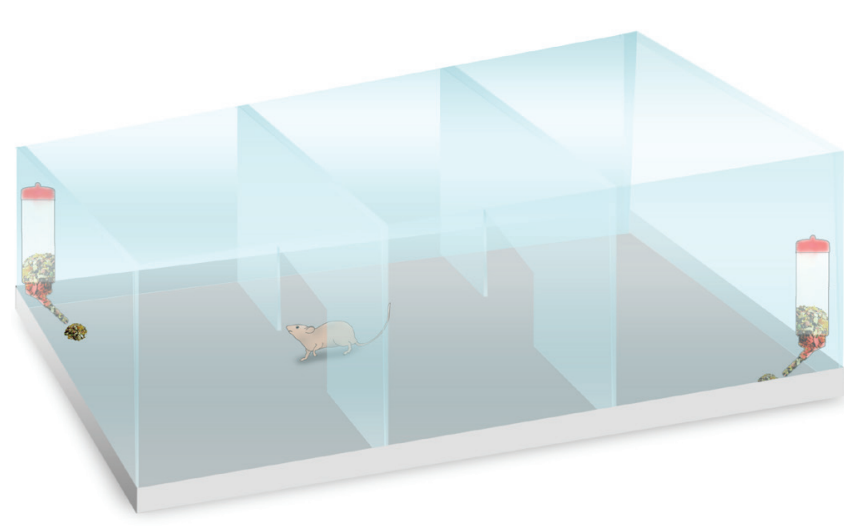

Şekil 4. Sosyal etkileşim testi düzeneği

\section{Saldırgan hayvana ya da saldırgan hayvan ile ilgili ipuçlarına (koku, tüy, ses vb) maruz bırakma testleri}

Stres temelli anksiyete oluşturmada kullanılan saldırgan hayvanın kendisinin ya da saldırgan hayvana ait koku, tüy, idrar, ses vb ipuçlarının kullanıldığı modeldir. Bu modelde sıçan arada bir ayırıcı bölmenin yer aldığı test düzeneğinde saldırgan hayvanın kendisi ile direkt olarak karşılaştırılmaktadır. Türünü tehdit eden saldırgan hayvan ile karşılaşan sıçan kendini koruma amaçlı donakalma hareketi göstermektedir.

Saldırgan hayvana ait ipucu olarak çoğunlukla kedi tüyü ya da islatılmış ve kirletilmiş kedi kumu kullanılmaktadır. Tüyün kullanıldığ 1 deneylerde aynı kedinin üzerine 2 gün boyunca giydirilmiş kumaştan aparatın, sıçanın bırakılacağı panelde yer alan plakaya kaplanarak kullanılmasıyla oluşturulmaktadır. Aynı kedi tarafindan 2 gün boyunca kullanılmış olan kirli ve ıslak kedi kumundan $125 \mathrm{ml}$ alınarak sıçanın yerleştirileceği 24x30x30 cm boyutlarındaki pleksiglass kaba aktarılır. Deneylerde sıçanların, 10 dakika boyunca tüy ve kokunun yedirildiği ya da kirletilmiş ve ıslatılmış kedi kumunun bulunduğu kaptaki davranışları incelenir. Korunmasız ortamda olduğunu farkeden sıçan, her an saldırgan hayvan ile karşılacağı endişesiyle ortamdan uzaklaşmak için çabalar. Deneyin sonlarına doğru sıçan çabalamaktan vazgeçip kabın kenar kısımlarında pusmuş bir şekilde çaresizlik duygusunun analoğu olan donakalma hareketi sergilemektedir. Sıçanın umutsuzluğa düşüp ortamdan uzaklaşma çabasından vazgeçerek donakalma süresindeki artış anksiyete düzeyi ile doğru orantılı olarak artmaktadır. Sıçanın bir stresöre maruz kalması ve bu stresöre maruz kalma süresinin uzaması sıçanda anksiyete gelişme olasılığını arttırmaktadır. Bir hafta sonra aynı sıçan bu defa temiz kumaş ya da temiz ve kuru kedi kumunun bulunduğu deney düzeneğine alınmaktadır. Siçanlara tekrarlanarak uygulanan hatırlatıcı etken olarak kullanılan saldırgan hayvan kokusu ya da saldırgan hayvan tüyü (temiz kumaş ya da temiz kedi kumu) maruz birakılma ile birden fazla kaçınılmaz travmatik deneyimler yaşatılmaktadır. Siçan ikinci kez saldırgan hayvana ait ipucuna maruz kaldığında, yeniden deneyimleme ile orijinal stresi yaşamaya zorlanmış olmaktadır [30-33].

\section{Olfaktor bulbektomi testi}

Siçanlar için koku alma temel duyu modalitesi olduğundan, olfakter bulbuslarının bilateral olarak alınması ile depresyon yaratılmaktadır [25, 34]. Bu modelin kullanıldığ 1 antidepresan aktivite değerlendirme çalışmalarında, sıçanların açık alandaki davranışlarında hiperaktivite azalması kaydedilmiştir [35].

\section{Kuyruktan asma testi}

Sıçanların kuyruklarından havaya asıldığı bir modeldir. Bu modelle de antidepresanların etkinliği değerlendirilmektedir. $\mathrm{Bu}$ testte siçanın hareketsiz kalıncaya kadar geçirdiği süre ölçülmektedir [20, 36].

\section{Ultrasonik vokalizasyon testi}

$\mathrm{Bu}$ model, korku ve benzeri emosyonel durumların anksiyeteden ayırtedilmesinde kullanılmaktadır. Farklı uyaranların (bir tehlike sinyali ardından kuyruktan elektrik şoku verilmesi gibi) oluşturduğu etkiler sıçanın çıkardığı ultrasonik seslerin frekans aralıkları ile karşılaştırılmaktadır. Düşük frekanslardaki sesler sıçanın kaçınılması gereken uyaran ile karşılaştığında, yüksek frekansdaki sesler ise sıçan oyun oynarken ya da mutlu olduğu zamanlarda ortaya çıkmaktadır. 18-32 kHz frekans aralığındaki sesler kaçınılmaz korku ve anksiyeteyi göstermektedir [37]. Bu model ile oluşturulan ayrıntılı spektrogramlar aracılı̆̆ıyla, standart davranış ölçümleri ile saptanamayan tedavinin etkisine bağlı ve bireysel farkları saptamak mümkün olmaktadır [38].

\section{Sonuç}

Deney hayvanlarında çeşitli stresörlerin kullanıldığ 1 bu çalışmalarda, genellikle aşırı irkilme, bilişsel bozukluklar, gelişmiş korku, düşük sosyal etkileşim gibi anksiyete davranışlarındaki değişimler ölçülmektedir. 
Sıçanların ansiyeteye verdikleri yanıtın gözlenmesi amacı ile incelenen lokomotor aktivite davranışındaki değişimlerin değerlendirilmesinde; açık alan, sosyal etkileşim ve olfaktor bulbektomi testlerinde düzeneğin değişik bölümlerinde geçirilen zaman; zorunlu yüzme testlerinde yüzme ve tırmanma hareketleri; ödül ve ceza sistemine dayalı çatışma testlerinde pedala basma sayısı; yükseltilmiş labirent testinde merkezde, açık ve kapalı kollarda geçirilen süre; kronik hafif stres testlerinde hareketlerdeki değişimler ölçülmektedir. Zorunlu yüzme testleri, labirent testleri, kronik hafif stres testleri, kuyruktan asma testi ve saldırgan hayvan ya da saldırgan hayvanla ilgili ipuçlarına maruz bırakma testlerinde donakalma ve hareketsizlik süreleri skorlanmaktadır. Kronik hafif stres ve sosyal etkileşim testlerinde ise ayrıca sıçanların yeme ve içme alışkanlıklarındaki değişimler gözlenmektedir. Ultrasonik test modeli ile farklı frekans aralıklarında elde edilen ses ölçümleri yoluyla standart davranış ölçümleri ile saptanamayan farklılıkların tespit edilmesi mümkün olmaktadır.

$\mathrm{Bu}$ modellerde incelenen anksiyete davranışları, altında yatan mekanizmaların araştırılması ve ilaçların etkinliğinin değerlerdirilmesinde yol gösterici olmaktadır. Her modelin özellikleri ve kullanım alanları göz önüne alındığında; kolay ve tekrarlanabilir olmalarının yanı sıra benzer davranış biçimlerinin gözlenebilmesi, geliştirilmekte olan ilaçların ya da benzerlerinin anksiyete tedavisinde klinik kullanım için yararlı olup olmayacaklarının daha etkin olarak araştırılabilmesine olanak sağlamaktadır.

\section{Teşekkür}

Bu yazıda kullanılmış olan şekiller Yakın Doğu Üniversitesi, Güzel Sanatlar ve Tasarım Fakültesi, Grafik Tasarımı Bölümü'nden Araştırma Görevlisi Raif M. Kızıl tarafından çizilmiştir. Raif Kızıl'a katkıları için teşekkür ederiz.

\section{Kaynaklar}

1. Diagnostic and Statistical Manual of Mental Disorders: DSM-V. Amer Psychiatric Pub Incorporated, 2013.

2. Barnett SA. The rat: a study in behavior. New Jersey: Transaction Publishers, 2007.

3. Belzung C, Misslin R, Vogel E. Anxiogenic effects of methyl- carboline-carboxylate in a light/dark choice situation. Pharmacol Biochem Behav 1987;28:29-33. doi:10.1016/00913057(90)90260-O

4. Montgomery KC. The relation between fear induced by novel stimulation and exploratory behaviour. J Comp Physiol Psychol 1955;48:254-60. doi: 10.1037/h0043788

5. Foa EB, Keane TM, Freidman MJ, Kohen JA, (editors).
Effective Treatments for PTSD: Practice Guidelines From the International Society of Traumatic Stress Studies. New York: Guilford Press, 2005.

6. Boissier JR, Simon P, Soubrie P, Airaksinen M, (editors). New approaches to the study of anxiety and anxiolytic drugs in animal: CNS and behavioral pharmacology. New York: Pergamon, 1976.

7. Ohl F. Testing for anxiety. Clin Neurosci Res 2003;3:233-8. doi:10.1016/S1566-2772(03)00084-7

8. Uzbay T. Depresyon Modelleri, PsikofarmakolojininTemelleri ve Deneysel Araştırma Teknikleri. Ankara: Çizgi Tıp Yayınevi, 2004.

9. Pynoos RS, Ritzmann RF, Steinberg, AM, Goenjian A, Prisecaru I. A behavioral animal model of post traumatic stress disorder featuring repeated exposure to situational reminders. Biol Psychiatry 1996;39:129-34. doi:10.1016/00063223(95)00088-7

10. Servatius RJ, Ottenweller JE, Natelson BH. Delayed startle sensitization distinguishes rats exposed to one or three stress sessions: Further evidence toward an animal model of PTSD. Biol Psychiatry 1995;38:539-46. doi:10.1016/00063223(94)00369-E

11. Rau V, De Cola JP, Fanselow MS. Stress-induced enhancement of fear learning: An animal model of post traumatic stress disorder. Neurosci Biobehav Rev 2005;29:1207-23. doi:10.1016/j.neubiorev.2005.04.010

12. Richter LG. Acute and long-term behavioral correlates of underwater trauma: Potential relevance to stress and post stress syndromes. Psychiatry Res 1998;79:73-83. doi:10.1016/ S0165-1781(98)00030-4

13. Kohda K, Harada K, Kato K, et al. Glucocorticoid receptor activation is involved in producing abnormal phenotypes of single prolonged stress rats: A putative post traumatic stress disorder model. Neurosci 2007;148:22-33. doi:10.1016/j. neuroscience.2007.05.041

14. Cohen, H, Joseph Z, Matar M. The relevance of differential response to trauma in an animal model of posttraumatic stress disorder. Bio Psychic 2003;53:463-73. doi:10.1016/S00063223(02)01909-1

15. Rodgers RJ, Dalvi A. Anxiety, defence and the elevated plusmaze. Neurosci Biobehav Rev 2007;21:801-10. doi: 10.1016/ SO149-7634(96)00058-9

16. Prut I, Belzung C. The open field as an a paradigm to measure the effects of drugs on anxiety-like behaviors: a review. Eur J of Pharmacol 2003;463:3-33. doi:10.1016/S00142999(03)01272-X

17. Belzung C. Measuring exploratory behavior. In: Crusio WE, Gerlai RT, editors. Handbook of Molecular Genetic Techniques for Brain and Behavior Research: Techniques in the Behavioral and Neural Sciences. Amsterdam: Elsevier, 1999:739-49.

18. Porsolt RD, Bertin A, Blavet N, et al. Behavioral despair in rats: a new model sensitive to antidepressant treatments. Eur J Pharmacol 1978;47:379-91.

19. Lucki I. The forced swimming test as a model for core and component behavioral effects of antidepressant drugs. Behav Pharmacol 1997;8:523-32.

20. Willner P. Animal models as simulations of depression. 
Trends Pharmacol Sci 1991;12:131-6. doi:10.1016/01656147(91)90529-2

21. Lyons DM. Animal models of anxiety disorders. In: Schatzberg AF, Nemeroff CB, editors. The American Psychiatric Publishing Texbook of Psychoparmacology. 4th edition. Arlington: American Psychiatric Publishing, 2009:153-9.

22. Vogel JR, Beer B, Clody DE. A simple and reliable conflict procedure for testing anti-anxiety agents. Psychopharmacol 1971;21:1-7.

23. Wall PM, Messier C. Methodological and conceptual issues in the use of the elevated plus-maze as a psychological measurement instrument of animal anxiety-like behavior. Neurosci Biobehav Rev 2001;25:275-86. doi:10.1016/S01497634(01)00013-6

24. Pellow S, Chopin P, File SE, Briley M. Validation of open:closed arm entries in an elevated plus-maze as a measure of anxiety in the rat. J Neurosci Methods 1985;14:149-67. doi:10.1016/0165-0270(85)90031-7

25. O'Neill MF, Moore NA. Animal models of depression: are there any? Hum Psychopharmacol Clin Exp 2003;18:239-54.

26. Willner P. Validity, reliability and utility of the chronic mild stress model of depression: a 10-year review and evaluation. Psychopharmacol 1997;134:319-29. doi: 10.1007/ s002130050456

27. Blanchard RJ, McKittrick CR, Blanchard DC. Animal model of social stress: effects on behavior and brain neuro- chemical systems. Physiol Behav 2001;73:261-71. doi:10.1016/S00319384(01)00449-8

28. Kocahan S, Akıllığlu K, Babar Melik E, Melik E. Beyin ve davranışlar üzerine sosyal çevrenin etkileri. İstanbul Tıp Derg 2010;73:108-12.

29. Hellemans KGC, Benge LC, Olmstead MC. Adolescent enrichment partially reverses the social isolation syndrome. Dev Brain Res 2004;150:103-15. doi: 10.1016/j. devbrainres.2004.03.003
30. Cohen H, Zoher J. An animal model of posttraumatic stress disorder: The use of cut-off behavioral criteria. Ann N Y Acad Sci 2004; 1032: 167-78. doi: 10.1196/annals.1314.014

31. Mazor A, Matar MA, Kaplan Z, Kozlovsky N, Zohar J, Cohen H. Gender-related qualitative differences in baseline and poststress anxiety responses are not reflected in the incidence of criterion-based PTSD-like behaviour patterns. Bio Pschy 2007;1:1-14. doi:10.1080/15622970701561383.

32. Kesner Y, Zohar J, Merenlender A, I Gispan, F Shalit, G Yadid. WFS1 gene as a putative biomarker for development of post-traumatic syndrome in an animal model. Mol Psychiatr 2009; 14: 86-94. doi:10.1038/sj.mp.4002109

33. Aykaç A, Aydın B, Cabadak H, Gören M. The change in muscarinic receptor subtypes in different brain regions of rats treated with uoxetine or propranolol in a model of posttraumatic stress disorder. Behav Brain Res 2012; 232:124-29. doi:10.1016/j.bbr.2012.04.002

34. Nowak G, Szewczyk B, Wieranska JM, et al. Antidepressant like effect of acute and chronic treatment with zinc in forced swim test and olfactory bulbectomy model in rat. Brain Res Bull 2003;61:159-64.

35. Kelly JP, Wrynn AS, Leonard BE. The olfactory bulbectomized rat as a model of depression: an update. Pharmacol Ther 1997;74:299-316. doi:10.1016/S0163-7258(97)00004-1

36. Steru L, Chermat R, Thierry B, Simon P. The tail suspension test: a new method for screening antidepressants in mice. Psychopharmacol 1985;85:367-70. doi:1 0.1007/BF00428203

37. Jelen P, Soltysik S, Zagrodzka J. 22-kHz Ultrasonic vocalization in rats as a index of anxiety but fear: behavioral pharmacological modulation of affective state. Behav Brain Res 2003;141:63-72. doi:10.1016/S0166-4328(02)00321-2

38. Brudzynski SM. Pharmacological and behavioral characteristic of $22 \mathrm{kHz}$ alarm calls in rats. Neurosci Biobehav Rev 2001;25:611-7. doi:10.1016/S0149-7634(01)00058-6 